\title{
Preservation of the structure of the building in the process of renovation of industrial architecture
}

\author{
Marina Gudina ${ }^{1 *}$, and Evgenii Prokofiev ${ }^{1}$ [0000-0003-0609-7176] \\ ${ }^{1}$ Kazan State University of Architecture and Engineering, 420043, Zelenaya st., Kazan, Russia
}

\begin{abstract}
The renovation of industrial buildings has become relevant recently with increasing interest in former industrial areas that need to rethink their importance in the city without losing their identity. Based on the previous scientific works of the authors, we reveal one of the principles of preserving identity in the renovation of industrial buildings - the principle of preserving the structural identity of the building. In this scientific study, we analyze the existing experience of preserving structures during renovation and consider this principle in practice, namely, the renovation of the mill building erected in 1912 in the urban-type settlement of Apastovo, Republic of Tatarstan, Russia. The practical significance of the work lies in the possibility of applying the results of the study in modern architectural practice, in particular in the reconstruction of industrial buildings in historical cities of Russia. This work can become the basis for further research, identifying valuable areas for the development of industrial formations.
\end{abstract}

Keywords: constructive structure, building, renovation, industrial architecture.

\section{Introduction}

The structure features of the building represent one of the characteristic features of the identity of its location, affecting the surrounding urban environment. Currently, the problem of preserving the structure of the building in the process of renovation of industrial areas is becoming more and more urgent. The fact is that the empty industrial buildings represent a huge potential for further development of the territory. The starting point for designing such a development can be the theoretical and practical research of various authors, the analysis and generalization of existing experience in this field.

The authors of the research considered the structural aspects of the building from different points of view:

- ecological: ecological approach (the design and reconstruction of buildings should be carried out within the framework of an environmentally friendly concept, so that energy sources should be renewable, and the object used in construction itself becomes part of the environment) [1], the use of traditional methods [2], energy-efficient approach (the authors

* Corresponding author: gudinaidea@gmail.com 
propose to repair an inactive industrial object by increasing the energy efficiency of the building, taking into account the functionality of the building) [3], the use of nanomaterials in the reconstruction of industrial buildings [4];

- practical: renovation in the Netherlands (the authors consider the types of urban renewal in the Netherlands, classifying them into three main categories: regional renewal, reconstruction of architectural heritage and adaptive reuse) [5], Irkutsk [6], Ulan-Ude (the paper examines the case of reconstruction of objects of the former distillery in Ulan-Ude and their revival and transformation into a Center of Contemporary art) [7], Italy [8], St. Petersburg (the authors trace the use of various transformation methods - reconstruction, restoration and new construction - on the examples of St. Petersburg historical industrial objects) [9], China [10,11, 12], Khabarovsk (on the example of the territory of the former Amur plant located in the southern part of the city, the possibility of replacing the old factory buildings and the adjacent territory with new, more technological and relevant industrial production for the city) [13], local reconstruction of load-bearing structures [14], standardization of industrial formations $[15,16]$,

- identity: filling the building and the surrounding area with meanings was considered in the work «Survey and preservation of an abandoned archaeological industrial site», where the authors considered the reconstruction of industrial spaces along the coast of Lazio, which are the first part of a larger urban renovation project, preserving the memory of the original structure [17], the directions of adaptation of industrial heritage to the modern context of the city [18], based on the principles of transpersonal socionics, a method is proposed, it allows us to provide a systematic unified approach to the development of programs for the renovation of depressive territories based on the consideration of all parties involved in this problem [19];

- technological: renovation using BIM technologies (studying layouts using Revit software) [20], IoT (a cognitive framework is proposed to assist the stages of operation from one construction aspect to the entire construction cycle) [21].

In this article, the authors want to show the importance of preserving the structural structure of the building, its impact on identity, and show the significance of this preservation by a practical example.

\subsection{Problem statement}

Modern socio-economic processes in the urban environment change the architectural appearance of industrial formations, complexes, and enterprises. Many industrial enterprises are closed, fall into disrepair, and their architectural appearance is destroyed. There is a problem of renovation of empty and fallen into disrepair buildings of industrial architecture.

The research hypothesis. It is assumed that a renovation of an industrial building will successful if the maximum possible structural features of the building are used, thus it is possible to emphasize the identity of the object, the aesthetic characteristics of the building and the places around it.

The purpose of the study: to identify and justify the need to preserve the structure of the building in the process of renovation of industrial architecture, to analyze and summarize the experience of renovation of industrial enterprises from the point of view of the structure, to develop a design solution for preserving the structure of the building of industrial architecture.

Based on the hypothesis and objectives of the study, the following tasks were set:

- to trace the evolution of the renovation of industrial formations in Russia and abroad;

- identify the factors that affect the change in the functional purpose due to the structural features of the building; 
- study the history of the planned territory and building;

- to develop a design solution for the preservation of the structural structure of the building in the process of renovation of industrial architecture on the example of the renovation of the mill building built in 1912 in the urban-type settlement (p. g. t.) Apastovo, Republic of Tatarstan, Russia.

\section{Materials and methods}

\subsection{Research process}

The historic building is a concentration of many functions and architectural forms. Therefore, the clash of the old and the new in this environment is becoming stronger. Renovation is usually used when changing the functional purpose of an object, which often involves adjusting the existing structure, urban environment and stylistic solution. It is rational to design the structures of industrial buildings taking into account their possible modifications; creating an adaptable, mobile environment is currently the most relevant direction in industrial architecture.

\subsubsection{The boundaries of the study}

- territorial (analytics: historical cities of Russia, foreign countries; project: Apastovo, Russia);

- structural-load-bearing walls-red brick;

- chronological (late 19th century - mid-20th century).

\subsubsection{Main research methods}

- analysis and generalization of existing practical experience in the preservation of structural features in the renovation of industrial buildings;

- field survey, photographing of an industrial building;

- structural analysis of an industrial building;

- application of the research results in practice.

An industrial mill building built in 1912 in the urban-type settlement of Apastovo, Republic of Tatarstan, Russia, was chosen as the object of the project study (Fig. 1, 2).

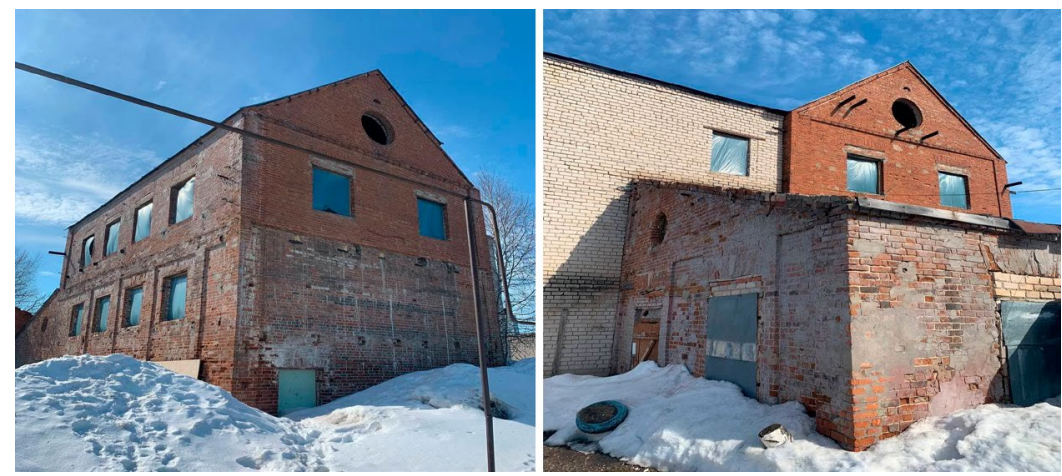

Fig. 1. Initial state of the object (2021). 


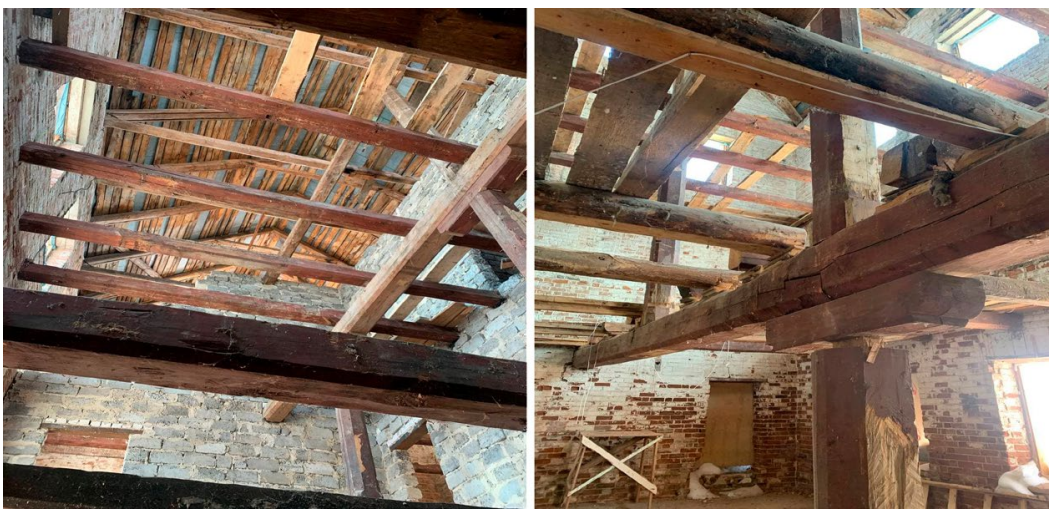

Fig. 2. Initial state of the object (2021).

The mill building was erected in 1912 (it is not a cultural heritage site), then in the 1990s it was converted into a dental clinic, but approximately starting from the 2000 s it has been empty. In 2021, it was decided to convert it into a youth center.

The building is made of red brick, three-storied; there are no floors between the stories in the old building, only beams remain. It is known that the west wing of the mill was demolished and rebuilt from silicate white brick, and the north wing of the building was demolished in 2019. The original brick walls with a thickness of $59 \mathrm{~cm}$ remained on the outer contour and two load-bearing ones inside. The internal partitions are made of cinder blocks, presumably they were erected during the operation of the dental clinic (Fig. 3). Figure 3 shows the initial state of the object: red is the red brick masonry, blue is the new white brick structure, and yellow is the demolished northern part of the building.

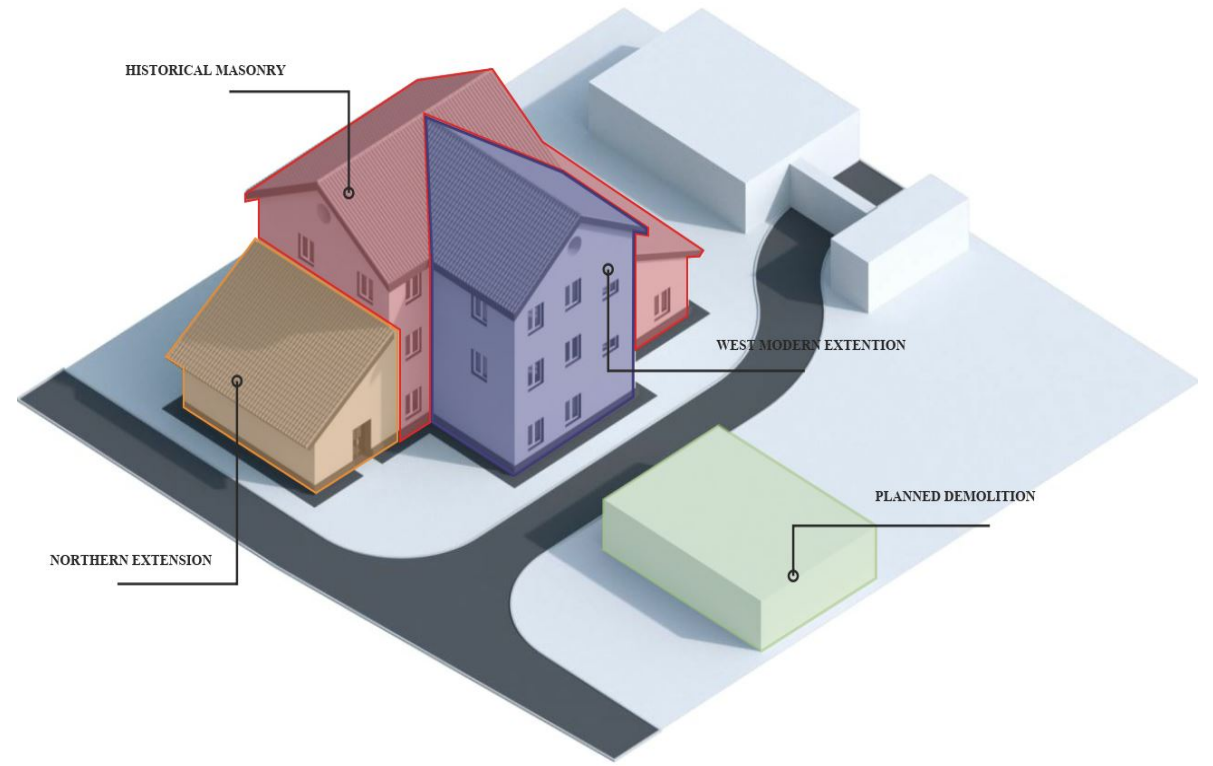

Fig. 3. The initial state of the object. Axonometry. 


\section{Results}

As a result of the study, the design experience of the renovation of industrial buildings was studied, the factors affecting the design features were identified and a project proposal for the renovation of an industrial building in Apastovo was formed with the preservation of the structure.

The analysis of objects of renovation of industrial architecture in Russia and abroad (Table 1.) showed that the objects of analysis are characterized by shell, frame-shell, barrel, wall, frame-barrel-diaphragm structural systems.

1. Shell-2 objects;

2. Frame-shell-4 objects;

3. Barrel design -2 objects;

4. Wall-1 object;

5. Frame-barrel-diaphragm - 1 object.

Table 1. Analysis of industrial architecture renovation projects in Russia and abroad.

\begin{tabular}{|c|c|c|c|c|}
\hline $\begin{array}{l}\text { Object/year of } \\
\text { construction }\end{array}$ & $\begin{array}{l}\text { Current } \\
\text { function }\end{array}$ & $\begin{array}{l}\text { Primary } \\
\text { function }\end{array}$ & Constructive system & $\begin{array}{c}\text { Type of } \\
\text { renovation }\end{array}$ \\
\hline \multicolumn{5}{|c|}{ Foreign projects } \\
\hline Echo Hou & $\begin{array}{c}\text { Coffee } \\
\text { shop/sho } \\
\text { p }\end{array}$ & $\begin{array}{c}\text { Warehous } \\
\mathrm{e}\end{array}$ & $\begin{array}{l}\text { Shell-shaped. Low-span } \\
\text { construction }\end{array}$ & $\begin{array}{l}\text { Integration of } \\
\text { new } \\
\text { construction. } \\
\text { Focus on } \\
\text { contrast }\end{array}$ \\
\hline $\begin{array}{c}\text { Quanzhou Vanke } \\
\text { «Tang» } \\
\text { Town/1984 }\end{array}$ & Gallery & Factory & $\begin{array}{c}\text { Frame-shell. Mid-span } \\
\text { construction }\end{array}$ & $\begin{array}{l}\text { Integration of } \\
\text { new } \\
\text { construction. } \\
\text { Equivalent } \\
\text { combination }\end{array}$ \\
\hline $\begin{array}{c}\text { St. Ann's } \\
\text { Warehouse/19th c.. }\end{array}$ & Theatre & $\begin{array}{c}\text { Warehous } \\
\text { e }\end{array}$ & Barrel design. Mid-span & $\begin{array}{c}\text { Integration of } \\
\text { new } \\
\text { construction. } \\
\text { Equivalent } \\
\text { combination }\end{array}$ \\
\hline $\begin{array}{c}\text { Edinburgh } \\
\text { Printmakers } / 20 \text { th } \mathrm{c} .\end{array}$ & Gallery & Factory & Barrel design. Mid-span & $\begin{array}{l}\text { Restoration } \\
\text { without } \\
\text { integration }\end{array}$ \\
\hline $\begin{array}{c}\text { Malmö } \\
\text { Saluhall/20th c }\end{array}$ & Market & $\begin{array}{l}\text { Cargo } \\
\text { base }\end{array}$ & $\begin{array}{l}\text { Frame-shell. Mid-span } \\
\text { construction }\end{array}$ & $\begin{array}{c}\text { Integration of } \\
\text { new } \\
\text { construction. } \\
\text { Equivalent } \\
\text { combination } \\
\end{array}$ \\
\hline
\end{tabular}


Continuation of table 1

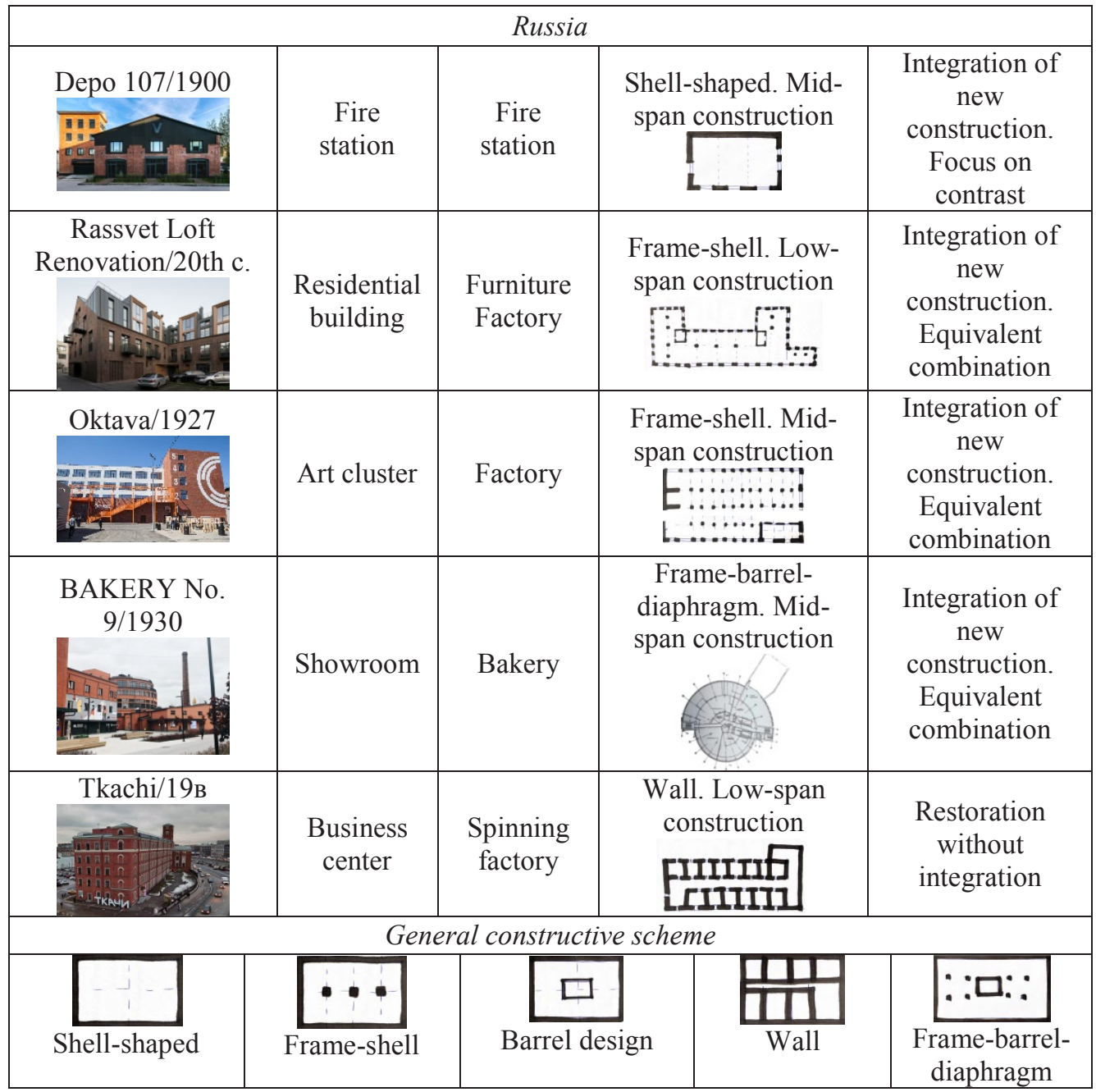

The regularity of the functional solution from the structural features of the building was also revealed:

For low-span structures, the division of space into small rooms is typical, which allows you to create residential premises, office or small retail (for example, Rassvet Loft Renovation, Weavers).

Medium-span structures are characterized by public use of buildings, for example, a gallery or an art cluster (Oktava, Edinburgh Printmakers).

For large-span structures, only public use is typical.

The project object has a medium-span wall structure, which means that such a system will be quite stable and from the point of view of functionality for public use, this object has its own justifications. Fig. 4 shows the materials of the original building in the project proposal. In Fig. 5, you can see the full volume sentence in axonometry. The visualization of the youth center is shown in Fig. 6.

The following constructive suggestions were made in the project:

- restoration of the demolished northern extension in modern materials;

- preservation of existing walls; 
- new design solution for the 3rd floor.

On the facade, these solutions were displayed as follows:

- facing with metal panels of the facade of the western annex;

- panoramic glazing of the 3rd floor;

- restoration of historic brickwork.

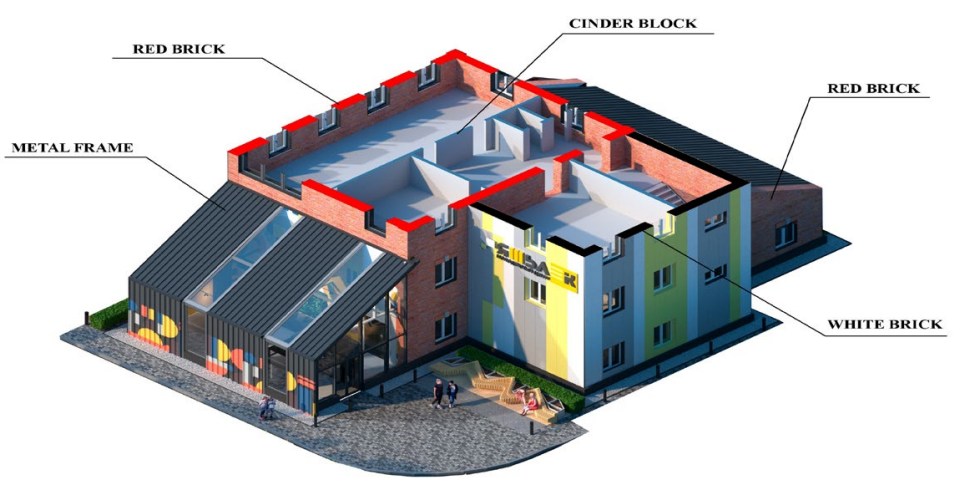

Fig. 4. Project proposal. Axonometry.

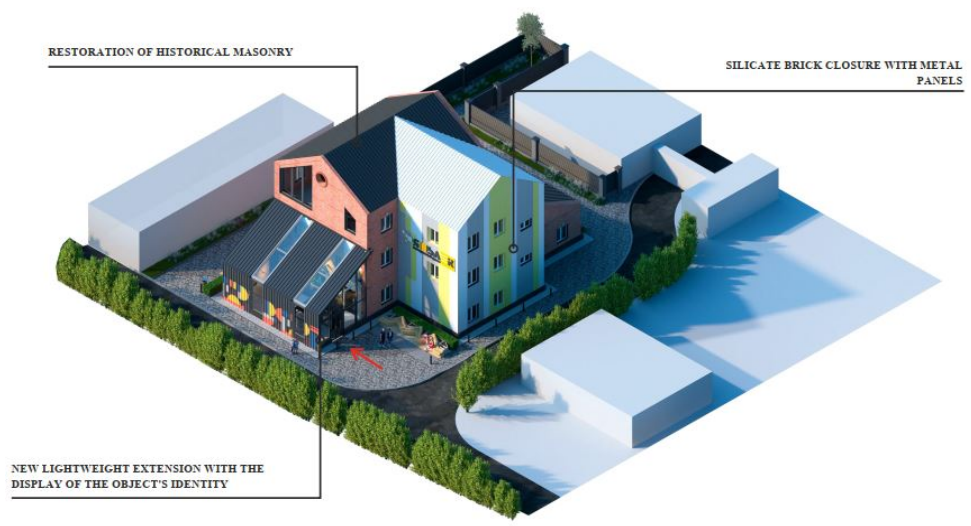

Fig. 5. Project proposal. Axonometry.

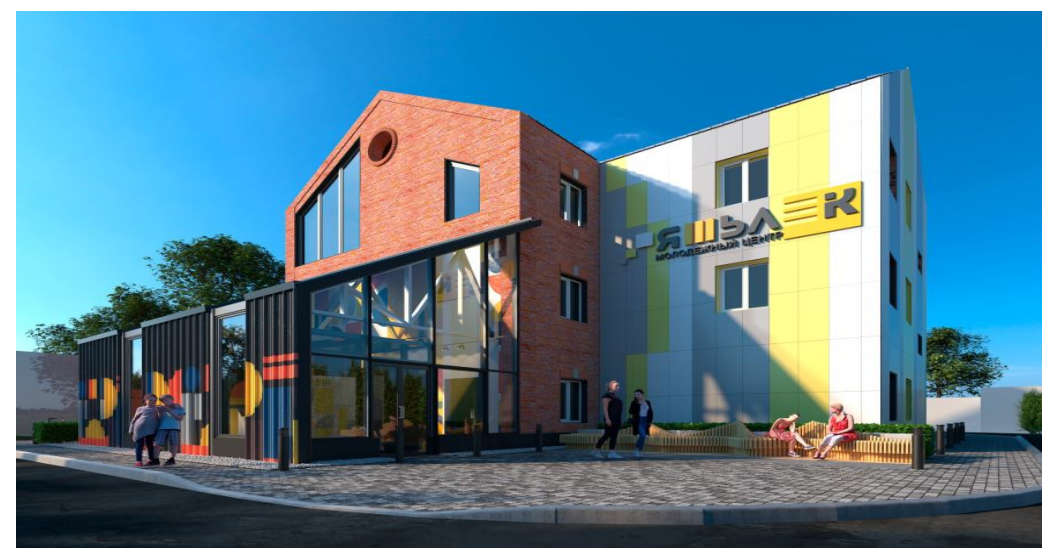

Fig. 6. Visualization of the project proposal. 


\section{Discussion}

The study concerns the renovation of capital buildings made of red brick. These objects were able to successfully express themselves in a new function and a new form with the maximum preservation of the original design. The project proposal also maximizes the use of the original design features so that they are used and shown in the best light.

With the described relevance, there are still cases in practice when industrial buildings are demolished, they are built from materials that carry their value not only constructive, but also historical, strongly rooted in the urban environment. As an example of the demolition of an industrial building (similar to the objects in the analysis given in Table 1), which was a landmark for the district, we can cite a group of buildings of «Sanitekhpribor» plant in Kazan, Russia. This object was also a project proposal in the Master thesis of the authors of the study. The demolition was carried out in 2020, when, for unknown reasons, the facade of the building first collapsed, and then it was decided to demolish the entire body of this building, along with the columns and enclosing structures. This is an incredible loss of heritage for the neighborhood and the city that could potentially be architecturally successful and could become a place of attraction. However, there is hope that the remaining buildings will not be demolished after.

\section{Conclusions}

The study solves the problem of identifying the evolution of the renovation of industrial formations in Russia and abroad, identifying the factors that affect the change in functional purpose due to the structural features of the building, and the practical application of the principle of preserving the structure of the building in the process of renovation of an industrial building.

\section{References}

1. P. V. Rozhkov, V. I. Prokopenko, I. A. Purikova, S. V. Tertitsa, Y. S. Dimitryuk, JETT, 8 (2), 839 (2020)

2. O. Roselló, International Archives of the Photogrammetry, Remote Sensing and Spatial Information Sciences - ISPRS Archives, 54 (M-1), 137 (2020) DOI: 10.5194/isprsarchives-XLIV-M-1-2020-137-2020

3. A. Tukhtamisheva, D. Adilova, G. Issabayev, D. Abildabekova, A. Iissova, JARDC, S 12 (3), 785 (2020) DOI: 10.5373/JARDCS/V12SP3/20201318

4. Z. Zhan, SAE Int. J. Mater. Manuf., 13 (2), 151 (2020) DOI: 10.4271/05-13-02-0011

5. L. Jing, L. Sun, F. Zhu, IOP Conference Series: EES, 526 (1), 012200 (2020) DOI: $10.1088 / 1755-1315 / 526 / 1 / 012200$

6. U. Ganzhurova, R. Selivanov, Project Baikal, 64, 140 (2020) DOI: 10.7480/projectbaikal.64.1650

7. S. Makotina, Project Baikal, 55, 52 (2018) DOI: 10.7480/projectbaikal.55.1282

8. M. V. Santi, A. Frangipane, Concrete industrial architecture in Italy 1950 - 1980: Documentation of a changing modern heritage, in Proceedings of the 15th International Docomomo Conference - Metamorphosis: The Continuity of Change, IDC 20182018, 28-31 August 2018, Cankarjev DomLjubljana, Slovenia (2018)

9. E. Smirnova, V. Zaikin, E3S Web of Conferences, 91 (2), 05030 (2018) DOI: 10.1051/e3sconf/20199105030

10. Z. Gong, L. Bridnia, E3S Web of Conferences 237, 040073 (2020) DOI: $10.1051 / \mathrm{e} 3$ sconf/202123704007 
11. W. Bi, Z. He, Research on form construction of art intervention in old renovation space, in Proceedings International Conference on Urban Engineering and Management Science, ICUEMS, 24-26 April 2020, Guangdong, China (2020) DOI: 10.1109/ICUEMS50872.2020.00111

12.Z. Qiao, D. Hui, J. Huang, JPCS, 1549 (2), 022073 (2020) DOI: 10.1088/17426596/1549/2/022073

13. S. A. Sadredinov, M. E. Bazilevich, IOP Conference Series: Materials Science and Engineering, 962 (3), 032068 (2020)

14. J. Krentowski, S. Mlonek, K. Ziminski, A. Tofiluk, IOP Conference Series: Materials Science and Engineering, 471 (8), 082057 (2018) DOI: 10.1088/1757899X/471/8/082057

15. A. F. Barco, É. Vareilles, P. Gaborit, M. Aldanondo, J. I. I. S., 49 (1), 119 (2017) DOI: 10.1007/s10844-016-0431-6

16. C. Mirarchi, M. N. Lucky, S. Ciuffreda, M. Signorini, S. Lupica Spagnolo, C. Bolognesi, B. Daniotti, A. Pavan, International Archives of the Photogrammetry, Remote Sensing and Spatial Information Sciences - ISPRS Archives, 43 (B4), 69 (2020) DOI: 10.5194/isprs-archives-XLIII-B4-2020-69-2020

17. M. G. D'Urso, V. Manzari, F. Cavaliere, B. Marana, F. Marmo, Survey and preservation of an abandoned archaeological industrial site, in Proceedings of the 4 International Conference on Metrology for Archaeology and Cultural Heritage, IMEKO, TC-4, 22-24 October 2020, Trento, Italy (2020)

18. N. V. Korosteleva, O. A. Rastyapina, IOP Conference Series: Materials Science and Engineering, 687 (5), 055017 (2019) DOI: 10.1088/1757-899X/687/5/055017

19. A. Suzdaleva, V. Kurochkina, M. Kuchkina, B. Jargalsaihan, E3S Web of Conferences, 217, 02003 (2020) DOI: $10.1051 / \mathrm{e} 3$ sconf/202021702003

20. M. Szopinska-Mularz, S. Lehmann, Future Cities and Environment, 5 (1), 4 (2019) $10.5334 /$ fce. 50

21. S. Rinaldi, P. Ferrari, A. Flammini, M. Pasetti, E. Sisinni, L.C. Tagliabue, A.C. Ciribini, F. Martinelli, S. Mangili, A Cognitive Strategy for Renovation and Maintenance of Buildings through IoT Technology, in Proceedings of IECON Proceedings (Industrial Electronics Conference), 19-21 October 2020, Singapore, Singapore (2020) DOI: 10.1109/IECON43393.2020.9254980 